\title{
Decision Support System to Determine Scholarship Recipients using Analytical Hierarchy Process Method
}

\author{
Yusup Triwibowo
}

Program Studi Pendidikan Teknik Informatika Dan Komputer, Jurusan Teknik Elektro Fakultas Teknik, Universitas Negeri Jakarta

\begin{tabular}{|c|c|}
\hline Article Info & ABSTRACT \\
\hline $\begin{array}{l}\text { Article history: } \\
\text { Received: } 21 / 04 / 2021 \\
\text { Revised: } 11 / 05 / 2021 \\
\text { Accepted: } 17 / 06 / 2021 \\
\text { Available online } 30 / 06 / 2021\end{array}$ & $\begin{array}{l}\text { Every year, the Faculty of Engineering, State University of Jakarta, } \\
\text { holds the registration for BBM and PPA scholarships. Each scholarship } \\
\text { has certain criteria to determine prospective scholarship recipients. } \\
\text { The number of determining criteria and the large number of applicants } \\
\text { raises the problem of how to determine prospective scholarship } \\
\text { recipients with a large number of criteria for a very large number of }\end{array}$ \\
\hline $\begin{array}{l}\text { Keywords: } \\
\text { Decision Support System, } \\
\text { Scholarship, } \\
\text { Analytical Hierarchy Process }\end{array}$ & $\begin{array}{l}\text { applicants. To assist the determination in determining eligible students } \\
\text { to receive scholarships, a decision support system is needed. This study } \\
\text { aims to produce a decision support system application for determining } \\
\text { scholarship recipients using a web-based Analytical Hierarchy Process } \\
\text { method. This research was conducted at the Faculty of Engineering, } \\
\text { State University of Jakarta from March } 2015 \text { to October } 2015 \text {. The } \\
\text { method used in making this decision support system uses the } \\
\text { Prototype development method. This web-based decision support } \\
\text { system for determining scholarship recipients is made using the PHP } \\
\text { programming language and MySQL database with XAMPP as the local } \\
\text { server. Functional testing of the website was tested by } 1 \text { expert (Head } \\
\text { of Subdivision for Student Affairs, Faculty of Engineering) by inputting } \\
20 \text { sample data for BBM scholarship applicants and } 20 \text { sample data for } \\
\text { PPA scholarship applicants in } 2015 \text { with } 15 \text { students quota for BBM } \\
\text { scholarship recipients and } 14 \text { students quota for PPA scholarship } \\
\text { recipients. Based on the results of the functional test on the sample } \\
\text { data entered on the website, } 15 \text { students received BBM scholarships } \\
\text { and } 15 \text { students were not accepted as recipients of BBM scholarships } \\
\text { and in the PPA scholarship, } 14 \text { students were accepted as recipients of } \\
\text { PPA scholarships and } 16 \text { students were not accepted as recipients of } \\
\text { PPA scholarships. Therefore, it can be concluded that the decision } \\
\text { support system using the AHP method functions well and can be used } \\
\text { in the process of determining scholarship recipients at the Faculty of } \\
\text { Engineering, State University of Jakarta. }\end{array}$ \\
\hline
\end{tabular}

This is an open access article under the CC BY-NC license.

\section{Corresponding Author:}

Yusuf Triwibowo,

Program Studi Pendidikan Teknik Informatika Dan Komputer,

Jurusan Teknik Elektro Fakultas Teknik, Universitas Negeri Jakarta

Email: yusup.triwibowo@gmail.com 


\section{Introduction}

One of the most basic human rights is to obtain a proper education as stated in the 1945 Constitution. When a person gets a good education, it will open up for him to get a better life. Realizing that education is very important, the state strongly supports every citizen to achieve the highest education. Some of them carry out free education programs and scholarship programs (Machali, 2012).

Scholarships can be said to be financing that does not come from own or parental funding, but is provided by the government, private companies, embassies, universities, as well as educational or research institutions, or also from the office where an employee works because of the achievements of an employee can be given the opportunity to improve human resource capacity through education. The fee is given to those who are entitled to receive it, mainly based on the classification, quality, and competence of the scholarship recipient (Oktavia, 2018) (ANANTA \& WIJAYANTI, 2013).

With this method, it is hoped that the assessment will be more precise because it is based on the priority value of the criteria that have been determined so that it will get more accurate results for who will receive the scholarship.

With the background previously described, the author wants to design or build a system that is able to assist in the selection of scholarship recipients at the Faculty of Engineering, State University of Jakarta in accordance with existing criteria and lift it into a study entitled "Decision Support System to Determine Scholarship Recipients By Analytical Hierarchy Process Method".

\section{Method}

\subsection{System Floating Method}

Prototyping is the rapid development and testing of working models (prototypes) of new applications through an iterative and interactive process commonly used by information systems experts and business experts. Prototyping is also called rapid application design (RAD) because it simplifies and speeds up system design (Savitri \& Hadi, 2018) (Ashby \& O’Brien, 2005) .

Some users have difficulty expressing their desire to get an application that suits their needs. This difficulty needs to be solved by the analyst by understanding user needs and translating them into a model (prototype). This model is then improved continuously until it is in accordance with user needs.

\subsection{1st Stage Prototype Making}

In making the first stage prototype of the scholarship decision support system development application, it is divided into three stages, namely:

a. Listen to Customer

At this stage we conduct interviews to analyze the general needs of the scholarship selection process. At this stage, the developer and client jointly define the overall objectives of the scholarship recipients' Decision Support System in this study, but do not define detailed requirements for its functions and features. From the results of interviews conducted with the Faculty of Engineering, it is known the general needs of the system to be built. In this process, an analysis that includes feasibility and system requirements analysis is produced.

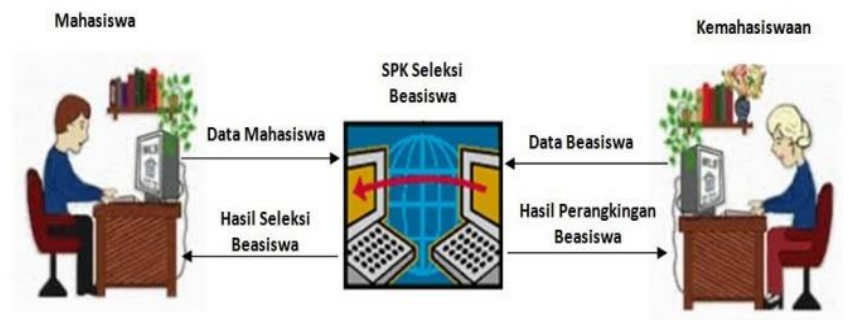

Figure 1. SPK as Scholarship Admission Information Provider 


\section{Results and Discussion}

\subsection{System Implementation}

The calculation of the weight of the criteria on the scholarship using the AHP method is the advantage of this scholarship acceptance decision support system, making it easier for the admin or scholarship manager to determine prospective scholarship recipients. The weighting of the scholarship criteria uses the AHP method, namely by determining the hierarchy or priority on a criterion on another criterion. Each priority level has a value, and the value at each priority level will be processed based on the AHP method, which will then be used as a weight for the scholarship criteria. The following table shows the results of the analysis on determining the priority of the interests of each attribute in each scholarship.

Testing on the Scholarship Decision Support System database is carried out through the website created. Through the website, users who have admin access rights can add, edit and delete attributes, study programs, scholarships, and students. Changes made through the software automatically change the database, for example, students register for scholarships, then the database must add one input data for students and their scores, as well as the others.

Tests on the Scholarship Decision Support System database have been carried out, and the results are running correctly, it can be seen in Figures 4.6 to 4.30. The following pictures and explanations show the GUI design that has been made.

Figure 2 of the main page viewed on the website. There is a register form right in the middle of the main page that is used by users to register themselves by filling in their bio on the register form. in this registration process all inputted data will be stored in the user table in the database. On this main page there is also a menu in the upper right corner of the created page, namely the login menu. The login menu on the page is used to direct the user to the login form to access the login on the website

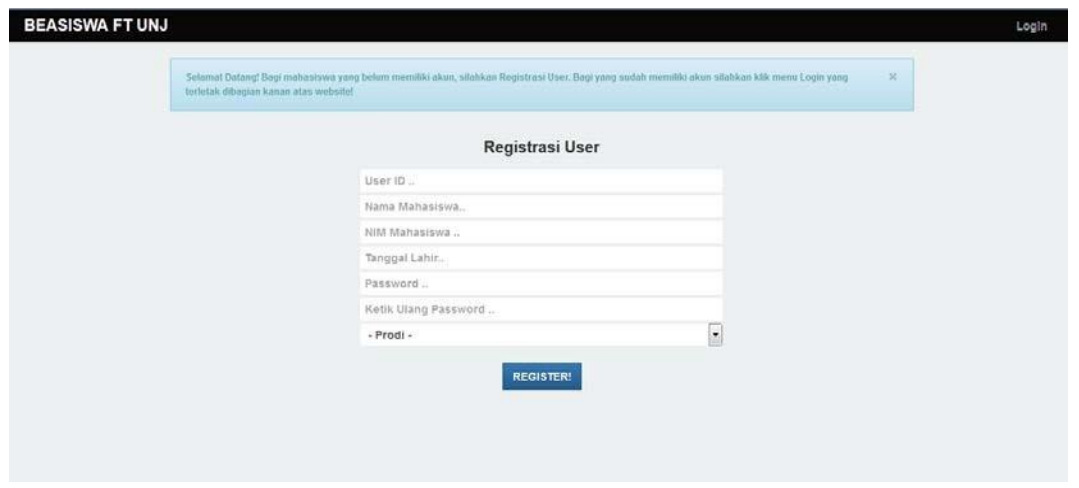

Figure 2. Main page

In Figure 2 shows the login form page on the website to access the website. The process carried out on this form is to check the contents of the user table in the database. If previously the user has registered and entered the correct data on the login form, the user will be directed to the home page on the website.

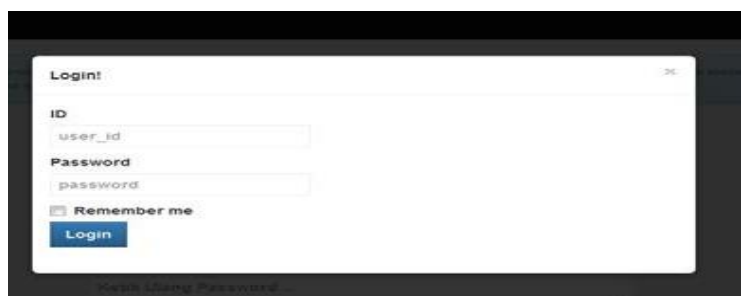

Figure 3. Login Form 
Home page is the main page for the user. The home page that is visible when students enter the website with the admin entering the website is different. Pages are created according to the needs of users and admins. The home page for admin and user will be shown in Figure 4.

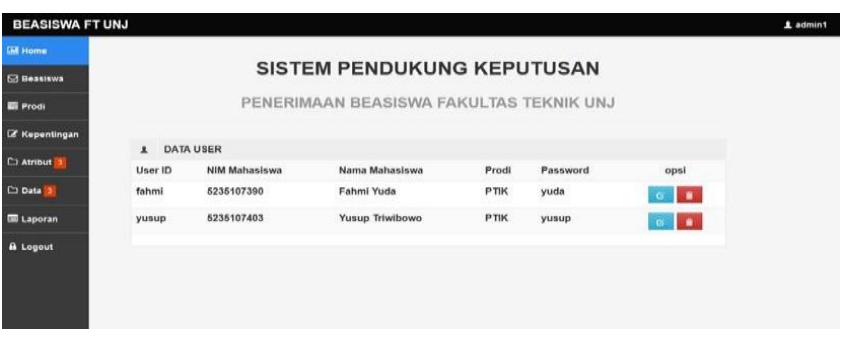

Figure 4. Admin Home Page

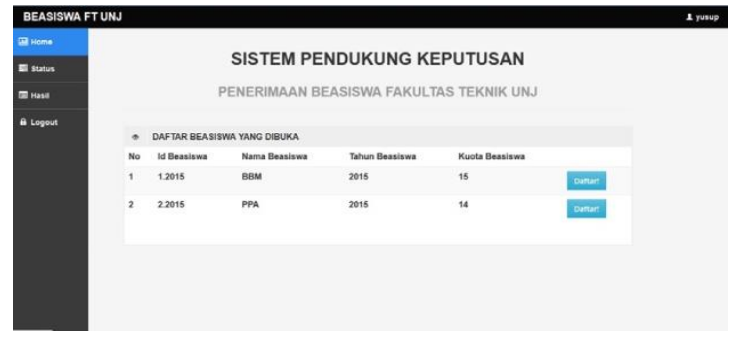

Figure 5. User home page

Figure 5 shows the home page for student users who have not been able to register if the admin does not input the criteria data for the registered scholarships. In the scholarship registration process by students, all data that looks like the scholarship to be registered, the criteria, along with the scholarship quota are the results of input that has been inputted by the previous admin.

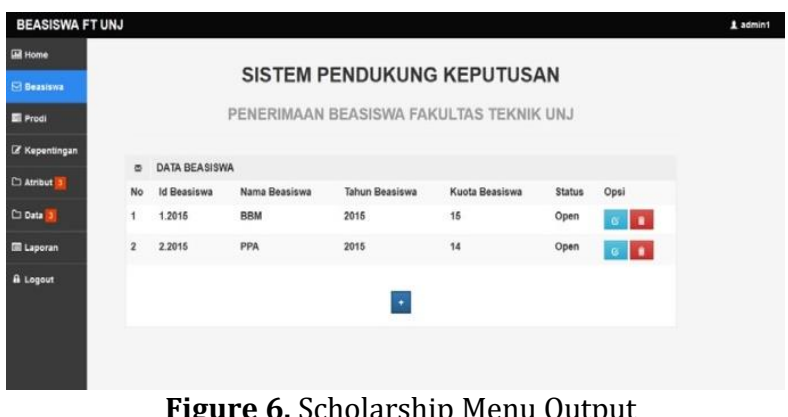

Figure 6. Scholarship Menu Output

In Figure 6 shows the admin home page, there is a scholarship menu. Scholarship menu is a menu that performs the process of adding, deleting, and changing the identity of the scholarship. The scholarship ID that is input is stored in the tbeasiswa database. The identity of the scholarship in this study, namely, the scholarship id, the type of scholarship, the year of the scholarship, the scholarship quota, and the status of the scholarship. Scholarship quotas are made useful during the final selection process for prospective scholarship recipients, after all scores are calculated per student, the steps taken are sorting student data according to grades and determining whether or not they are accepted by comparing the ranking values in the sorting data and then comparing with the selected scholarship quota. . The additional scholarship form will be shown in Figure 7. 


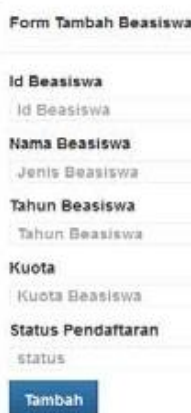

Figure 7. Add scholarship form

In addition to the scholarship menu, there is also a study program menu on the admin home page. The study program menu is the menu for adding, deleting, and changing identities for the list of study programs in a faculty. The display on the study program menu is shown in Figure 8.

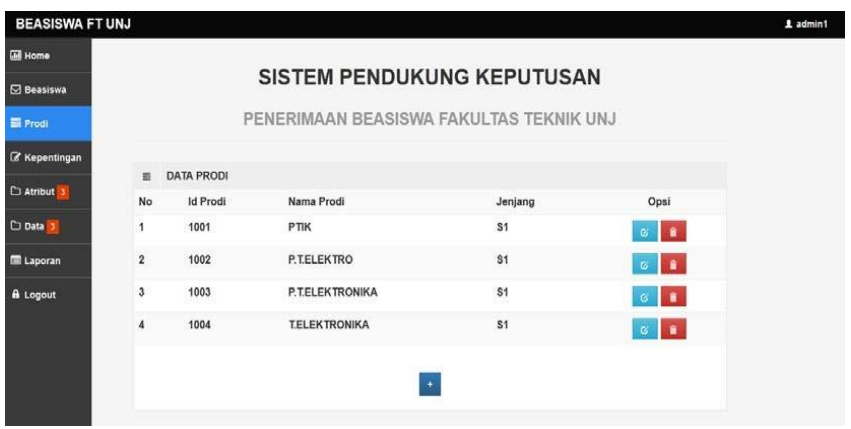

Figure 8. Study Program Menu Output

The identity of the study program that is input is stored in the tprodi database. The identity of the study program in this study is the study program id, the name of the study program, and the level. The identity of the study program entered is useful for one of the attributes of student biodata for registration on the website. The additional study program form is shown in Figure 9.

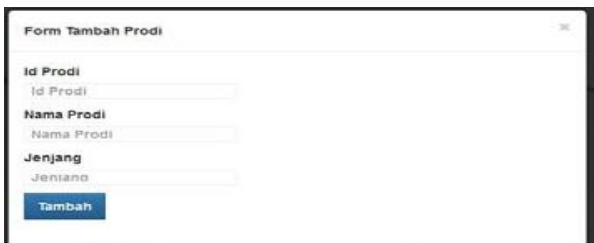

Figure 9. Add Study Program

In addition to the scholarship and study program menu, there is also an interest menu on the admin home page. Interest menu is a menu in which you can add, delete, and change interests. The display on the importance menu is shown in Figure 10. 


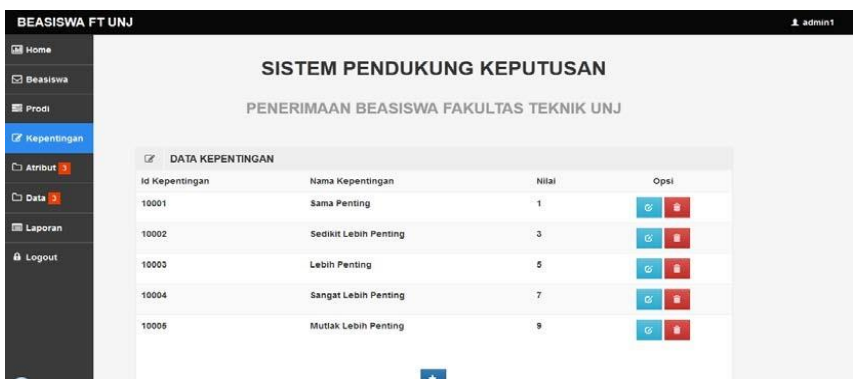

Figure 10. Interest Menu Output

The identity of the interests in this study, namely, interest id, name of interest, and value. This interest will later be used to perform a hierarchy between attributes. The added interest form is shown in Figure 11.

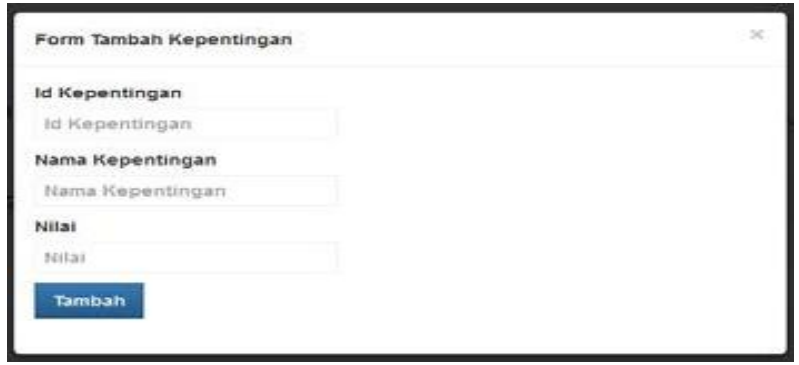

Figure 11. Add Interest Form

In addition to the scholarship, study program, and interests menu, there is also an attribute menu on the admin home page. The attribute menu is an input menu that performs the process of adding, deleting and changing the identity of attribute data on a scholarship. The display on the attribute menu is shown in Figure 12.

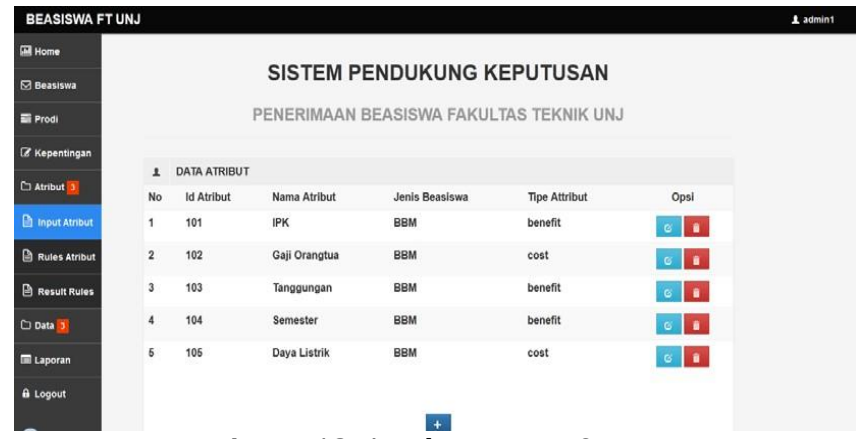

Figure 12. Attribute Menu Output

The input attribute identity will be stored in the attribute database. The identity of the attributes in this study are attribute id, attribute name, scholarship id, and attribute type. The scholarship id input in the attribute input process is to determine the inputted attributes including attributes for a scholarship. The attribute type input during the attribute input process is useful for the calculation process in the AHP method. Each attribute type has a different calculation process. Attribute types consist of 'Benefit' and 'Cost'. The add attribute form is shown in Figure 13. 


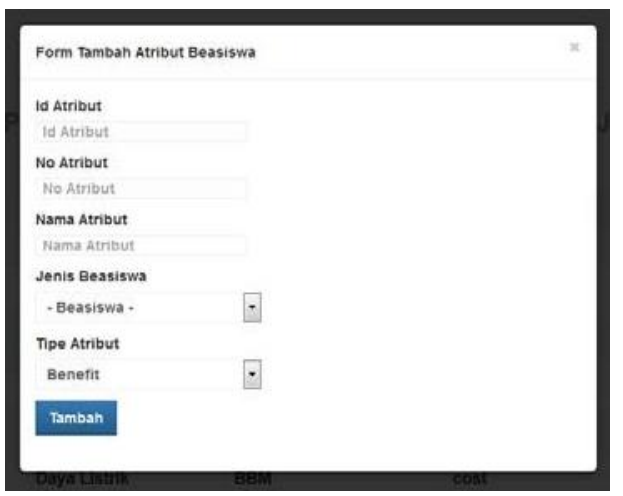

Figure 13. Add Attribute Form

In addition to the scholarship, study program, interests and attributes menu, there is also an attribute rules menu on the admin home page. The attribute rules menu is a menu in which you can add and delete attribute rules. The display on the sub-attribute menu is shown in Figure 14.

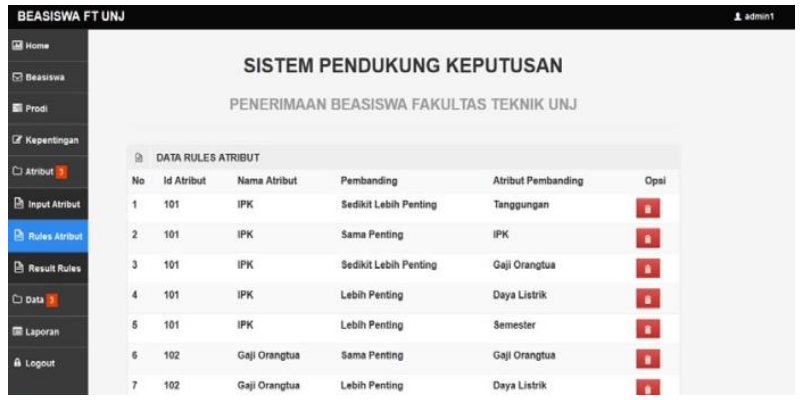

Figure 14. Output Menu Rules Attribute

Identifies the entered attribute rules will be stored in the tanalytic database.

The identity of the attribute rules in this study are analytic id, attribute id1, attribute id2, and interest id. These attribute rules will later be used to perform a hierarchy between attributes. The form for adding attribute rules is shown in Figure 15.

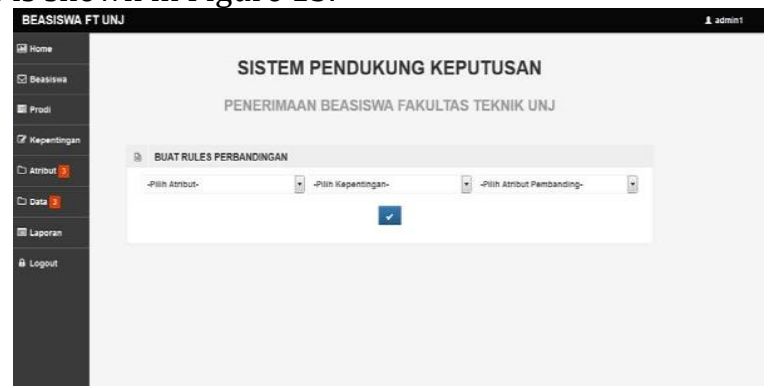

Figure 15. Form Add Attribute Rules

In addition to the scholarship menu, study programs, interests, attributes and attribute rules, there is also a result rules menu. The result rules menu is a menu in which it will display the results of the attribute value calculation process based on the attribute rules. The display on the result rules attribute menu is shown in Figure 16. 


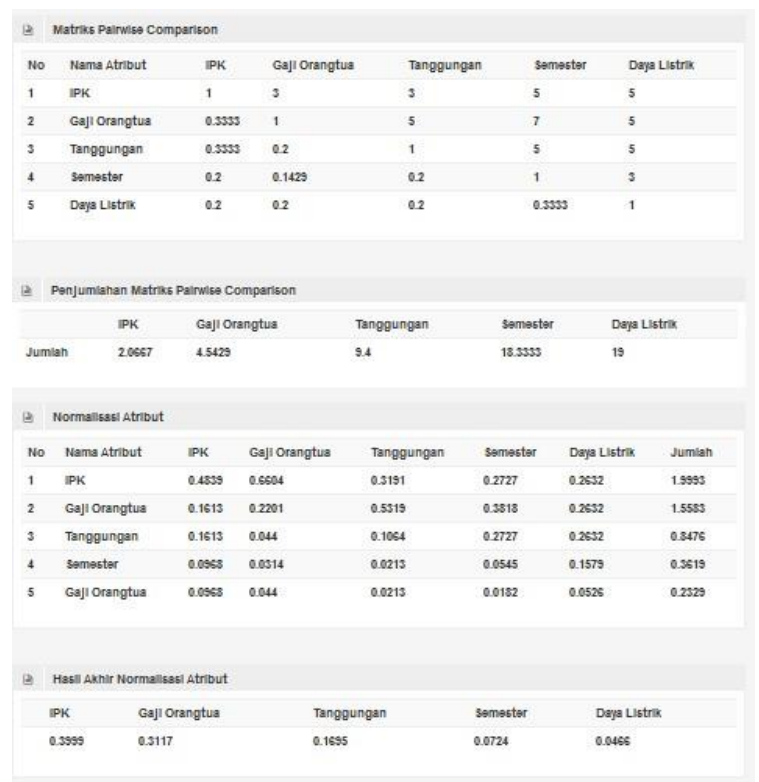

Figure 16. Output Menu Result Rules

In addition to the scholarship menu, study programs, attributes, interests, attribute rules, and result rules, there is also a student menu on the admin home page. Student menu is an input menu for student biodata for registration of a scholarship.

The display on the student menu is shown in Figure 17.

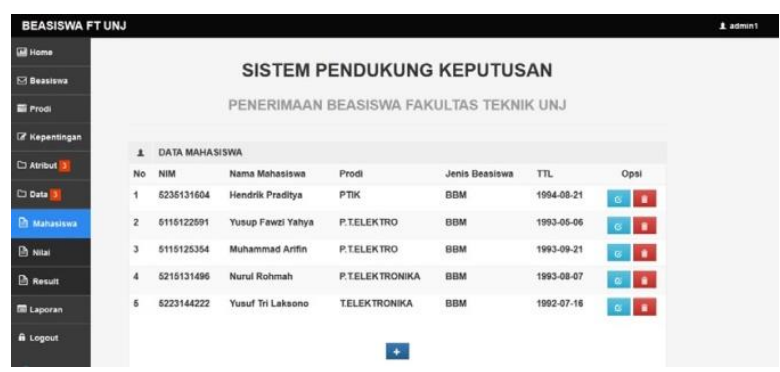

Figure 17. Student Mmenu Output

The student identification that is input is stored in the student database. The identity of the students in this study, namely, list id, student id, student name, study program id, scholarship id, and ttl. The scholarship id on the student menu input is by selecting the scholarship to be registered. The list of scholarships shown is the input from the scholarship menu, then takes the scholarship id and displays the scholarship on the add student data form. The form for adding student data is shown in Figure 18. 


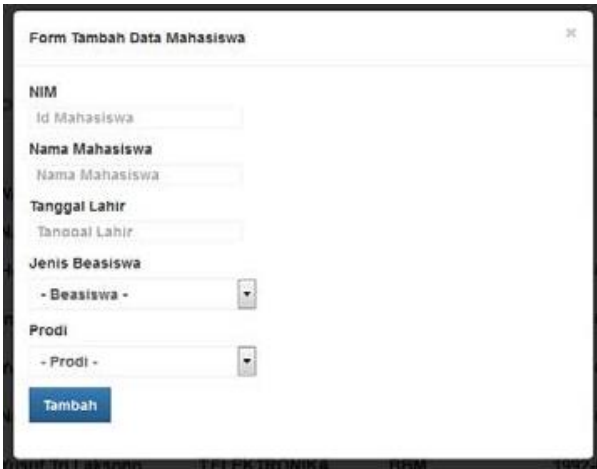

Figure 18. Add Student Data Form

In addition to the scholarship menu, study program, attributes, interests, attribute rules, result rules and students, there is also a value menu on the admin home page. Value menu is an input menu for attribute values registered to students on a scholarship. The display on the value menu is shown in Figure 19.

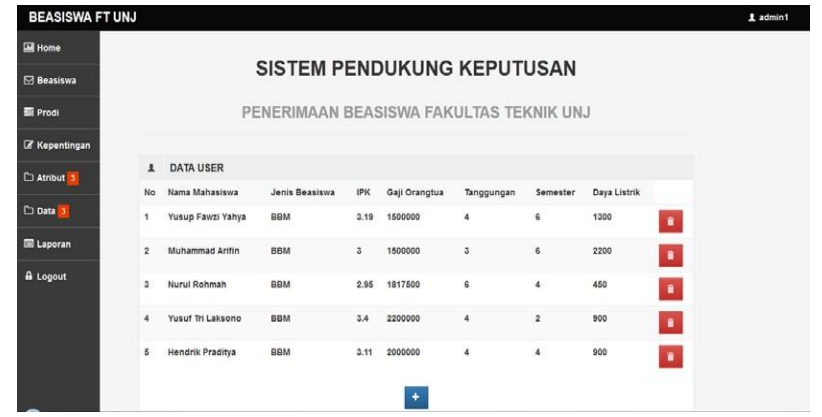

Figure 19. Value menu output

Identifies the input value is stored in the tvalue database. The identity of the values in this study are list id, student id, scholarship id, and sub-attribute id. The student id in the value menu refers to the input results from the student menu stored in the student table. Scholarships in the value menu refer to the input results from the scholarship menu stored in the tbeasiswa table. The student grade input form is shown in Figure 20.

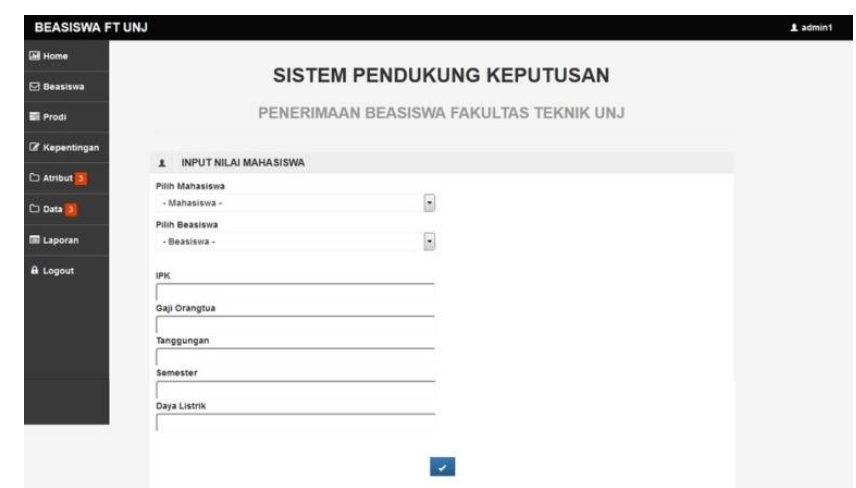

Figure 20. Student value data input form

After the admin has prepared the scholarship data and attributes, the next step is to change the scholarship status on the scholarship menu. The status of the scholarship so that it can be registered with students is 'Open'. After changing the scholarship status, students can apply for a scholarship. 


\section{Conclusion}

From several explanations that have been put forward in previous chapters, it can be concluded that this decision support system aims to assist users or scholarship providers in processing student data, scholarship applications, selection results and reports. Calculations on the system to perform the selection use the AHP (Analytical Hierarchy Processes) method. The stages of the decision support system development process in this research are listen to customer, build/revise mock-ups, and costumer test drives mock-ups. The results of the calculation of the AHP scholarship decision support system are ranked from the highest to the lowest value and the highest value is the result required for consideration by the user to obtain a scholarship.

Based on testing the functional requirements in table 4.14 on the system that has been made in this study, it can be concluded that this system has been successfully developed and functions well and can be utilized in

\section{Reference}

ANANTA, N. A. D. I., \& WIJAYANTI, S. (2013). Sistem Pendukung Keputusan Rekomendasi Kelayakan Penerima Beasiswa Prestasi Menggunakan Metode AHP.

Ashby, F. G., \& O’Brien, J. B. (2005). Category learning and multiple memory systems. Trends in Cognitive Sciences, $9(2), 83-89$.

Machali, I. (2012). Islam Memandang Hak Asasi Pendidikan. Jurnal Pendidikan Islam UIN Sunan Gunung Djati, 27(1), 1-20.

Oktavia, P. (2018). Sistem Pendukung Keputusan Seleksi Penerima Beasiswa dengan Metode Weighted Product pada SMP Negeri 1 Parung Berbasis Web. Jurnal Informatika Universitas Pamulang, 3(2), 80-86.

Savitri, P., \& Hadi, T. (2018). Implementasi Metode Forward Chaining Dalam Sistem Pendeteksi Kerusakan Hardware Pada Komputer Dan Laptop Berbasis Android. Simetris: Jurnal Teknik Mesin, Elektro Dan Ilmu Komputer, 9(1), 623-632.

Darmawan, D. 2013. Sistem Informasi Manajemen. Bandung: PT Remaja Rosdakarya.

Hartono, B. 2013. Sistem Informasi Manajemen Berbasis Komputer. Jakarta: PT Rineka Cipta.

Kadir, A. 2013. Pengenalan Teknologi Informasi. Jakarta: CV Andi Offset.

Kusumadewi, S. 2077. Fuzzy Multiple-Atribut Decision Making (Fuzzy MADM). Yogyakarta: Graha Ilmu. Nugroho, A. 2011. Perancangan dan Implementasi Sistem Basis Data. Yogyakarta : CV Andi Offset.

Soetam, R. 2011. Konsep Dasar Rekayasa Perangkat Lunak. Jakarta: PT Prestasi Pustaka Raya.

Sutabri, T. 2012. Konsep Sistem Informasi. Yogyakarta: CV Andi Offset.

Tim Penyusun. 2012. Buku Pedoman Skripsi/Karya Inovatif/Komprehensif. Jakarta: Fakultas Teknik,Universitas Negeri Jakarta.

Turban, E. 2005. Decision Support System and Intelligent System 7 th Ed. New Jersey: Pearson Education. Winarno, E. 2011. Easy Web Programming with PHP plus HTML5. Jakarta: PT Elex Media Komputindo. 